\title{
Cities, Poverty and Food: The role of municipalities in enhancing food security
}

Adrino Mazenda, ${ }^{1}$ Tinashe Mushayanyama, ${ }^{2}$ Tyanai Masiya,${ }^{3}$ and Moreblessing Simawu ${ }^{4}$

\begin{tabular}{|c|c|}
\hline A R T I C L E I N F O & A B S T R A C T \\
\hline Received: May 02, 2021 & $\begin{array}{l}\text { Food security is a critical issue in most African cities. Local } \\
\text { government initiatives such as the City of Johannesburg }\end{array}$ \\
\hline $\begin{array}{l}\text { Received in revised } \\
\text { form: September 03, } \\
2021\end{array}$ & $\begin{array}{l}\text { Food Resilience Strategy are established to enhance food } \\
\text { security in the city. The article draws insight from literature } \\
\text { across multiple disciplines to examine the extent to which } \\
\text { the Food Resilience Strategy relates food security to the }\end{array}$ \\
\hline $\begin{array}{l}\text { Accepted: September } \\
07,2021\end{array}$ & $\begin{array}{l}\text { economic challenges which citizens face. It discusses } \\
\text { critical themes for sustainable urban food security namely, } \\
\text { skills capacity and knowledge transference, access to land }\end{array}$ \\
\hline Published online: & and water, institutional challenges, economic factors, urban \\
\hline September 24, 2021 & $\begin{array}{l}\text { agriculture production and environmental factors. Finally, } \\
\text { the article recommends an integration of diverse } \\
\text { stakeholders in the design and implementation of the Food } \\
\text { Resilience Strategy, and thereby foster synergies between } \\
\text { local producers and the local food market. }\end{array}$ \\
\hline
\end{tabular}

Keywords: Food security, Poverty, Food Resilience Strategy, City of Johannesburg Municipality; South Africa

To cite this article: Mazenda, A., Mushayanyama, T., Masiya, T., Simawu, M. (2021). Cities, Poverty and Food: The role of municipalities in enhancing food security. Urbana, 22, 26-43. Retrieved from http://www.urbanauapp.org https://doi.org/10.47785/urbana.3.2021

\footnotetext{
${ }^{1}$ Correspondence author. School of Public Management \& Administration, University of Pretoria, Cnr Lynwood \& Roper Street, Hatfield, Pretoria, South Africa: adrino.mazenda@up.ac.za +27 768070463

${ }^{2}$ School of Public Management \& Administration, University of Pretoria, Cnr Lynwood \& Roper Street, Hatfield, Pretoria, South Africa; Tinashe 95@gmail.com +27 735187860

${ }^{3}$ School of Public Management \& Administration, University of Pretoria, Cnr Lynwood \& Roper Street, Hatfield, Pretoria, South Africa; tyanai.masiya@up.ac.za +27643961576

${ }^{4}$ Department of Economics, University of Fort Hare, P. Bag X1314 King Williams Town Road, Alice, South Africa.; msimawu@gmail.com. +27 683692705
} 


\section{Introduction}

Food insecurity has been a growing concern in most South African urban cities since 1994 (du Toit, 2011). Food security is defined as when citizens always have adequate access to physical, economical, healthy and nutritious food to satisfy their dietary requirements and a selection of food to lead a healthy lifestyle (United Nations Human Rights Council, 2007). Extant literature reveals that the poor in Johannesburg are vulnerable and struggle to access services and opportunities to enhance their livelihoods (Ahs, 2017; CoJ IDP, 2018). To address food security concerns, the City of Johannesburg Metropolitan Municipality (CoJ) created the Food Resilience Strategy (FRS) to reduce hunger, alleviate poverty, and promote food security in the city.

Hendricks (2013:4) argues that due to the nature and complexity of food security, policies need to be comprehensive, and encompass various food security elements. The CoJ FRS is administered through three structures, namely: food access, urban agricultural support and the promotion of healthy eating and lifestyles (CoJ Integrated Development Plan, 2013). The threetier system of the Food Resilience Strategy provides interventions to food security through food parcels, food packages, and backyard gardens. Secondly, interventions are provided by supporting the informal food supply system by encouraging local farmer cooperation's to provide farming advice, perform assessments, and assist financially. Finally, intervention is provided by supporting urban agriculture where feasible, through land packaging and establishment of hubs to connect local produce to cold chains, wide distribution networks, and packing houses (CoJ IDP, 2013).

The CoJ IDP 2018/2019 states that food insecurity is a major social problem within the city. Approximately $18 \%$ of the city's settlers have inadequate access to food due to poverty, unemployment and lack of income. According to the CoJ former Mayor Parks Tau, "Food insecurity has remained a development challenge that the city plans to eradicate in the future" (CoJ IDP, 2018:16). The challenge is not only limited to accessibility but also health and nutrition, level of productivity and earnings, social tensions, and crime (CoJ IDP, 2013:81).

The key strategies implemented by the CoJ through the FRS are, therefore, necessary to cushion food insecurity and protect the city against food shocks (CoJ IDP, 2018:16).

Despite the significance of food security in African cities such as Johannesburg, limited research has been conducted to explore the extent thereof. Substantial research is essential to provide practical input into planning and policymaking to address the problem and plan proactively to reduce urban food insecurity. To this extent, this article seeks to respond to the following questions:

- To what extent does the CoJ Food Resilience Strategy relate food security to citizens' economic challenges?

- What challenges are faced by the CoJ to implement the Food Resilience Strategy?

- What measures can the CoJ take to enhance its implementation of the Food Resilience Strategy?

This article responds to the above research questions through a qualitative case study design and extensive utilisation of document analysis. It analyses the methodology of various literature which provides a broad but critical and consolidated perspective of various authors discussions relevant to the design and implementation of food security in the CoJ. The article examines into the role of municipalities to address food insecurity in the context of poverty and the ongoing CoJ FRS safety net. With food security poised to become a primary urban challenge, focus on examining key strategies implemented by the CoJ through the FRS provides opportunities for the city and other municipalities to take reflective action to enhance food security. As a result, this article represents a unique but necessary approach to urban food security strategies such as 
agricultural reform and supports the identification of challenges and opportunities for enhancement.

The article contends that socioeconomic factors should be considered when developing and implementing food security policies. It also provides a compelling context for the need to collaborate with state organs to provide necessary food-related solutions. Overall, this research contributes towards enhancing food security in local municipalities by providing recommendations to create better accessibility and availability to food between local producers and markets. Furthermore, the article advises planning consultants and policymakers on how to assess the threat and proactively plan to inhibit the urban food deficit. The article makes a valid contribution to reduce urban food insecurity in CoJ and Africa.

\section{Literature Review}

Food insecurity and famines affect rural and urban populations alike in many developing countries. Hence, local governments adopt various strategies to enhance food security. The objective of the implementation of the CoJ FRS is to tackle food insecurity. According to Sen (1980) in Devereux (2001), the problem of food security and famine is not about the failure of food supply but rather about access to food. At the household level, access to food is considered achieved when it acquires food of sufficient quantity and quality to ensure a safe and nutritious diet (FOA, 2006). To realise access to food, not only domestic and local food should be realised, but households must also have access to the necessary resources to acquire food. However, high food prices compromise this access dimension, and consequently, result in low food quality, quantity, and variety.

In the context of poverty and famine, the entitlement approach aims to describe all legal sources of food comprehensively, which Sen (1981, p. 2) reduces to the following four categories - "production-based entitlement" (growing food), "trade-based entitlement" (buying food), "ownlabour entitlement" (working for food) and "inheritance and transfer entitlement" (being given food by others). A person's "entitlement set" is the full range of goods and services which they can acquire by converting their "endowments" (assets and resources, including labour-power) through "exchange entitlement mappings". According to Sen (1981), individuals face starvation if their full entitlement set does not provide adequate food for subsistence. Famine scales this up: occupationally or geographically related groups face famine if they experience catastrophic declines in their entitlements simultaneously. Perhaps the most valuable contribution of the entitlement approach to famine theorising is that it shifts the analytical focus away from a fixation on food supplies (the Malthusian logic of "too many people, too little food") and the inability of groups of people to acquire food. Food insecurity affects people who cannot access adequate food (e.g., because of poverty). Irrespective of the availability of food, a famine can occur even if food supplies are adequate and markets are functioning well, which is a crucial perception. Sen (1981) accentuated that there is no technical reason for markets to meet subsistence needs and no moral or legal reason why they should. An equally important insight that has generated much confusion and controversy in the literature is that famine can be caused by "exchange entitlement decline" (adverse shifts in the exchange value of endowments for food, e.g., falling wages or livestock rising food prices). It can also be caused by "direct entitlement decline" (for example, loss of food crops to drought) (Devereux, 2001). The entitlement approach does not exclude the latter's possibility.

Figure 1 below illustrates the conceptual framework on the relationship between civil society, such as the city's households, small-scale urban farmers (own gardens or cooperatives), non-profit organisations and other relevant stakeholders in the CoJ FRS institutional structure. The 
conceptual framework draws from the preceding discussion on Sen's entitlement approach contextualising the social capital theory.

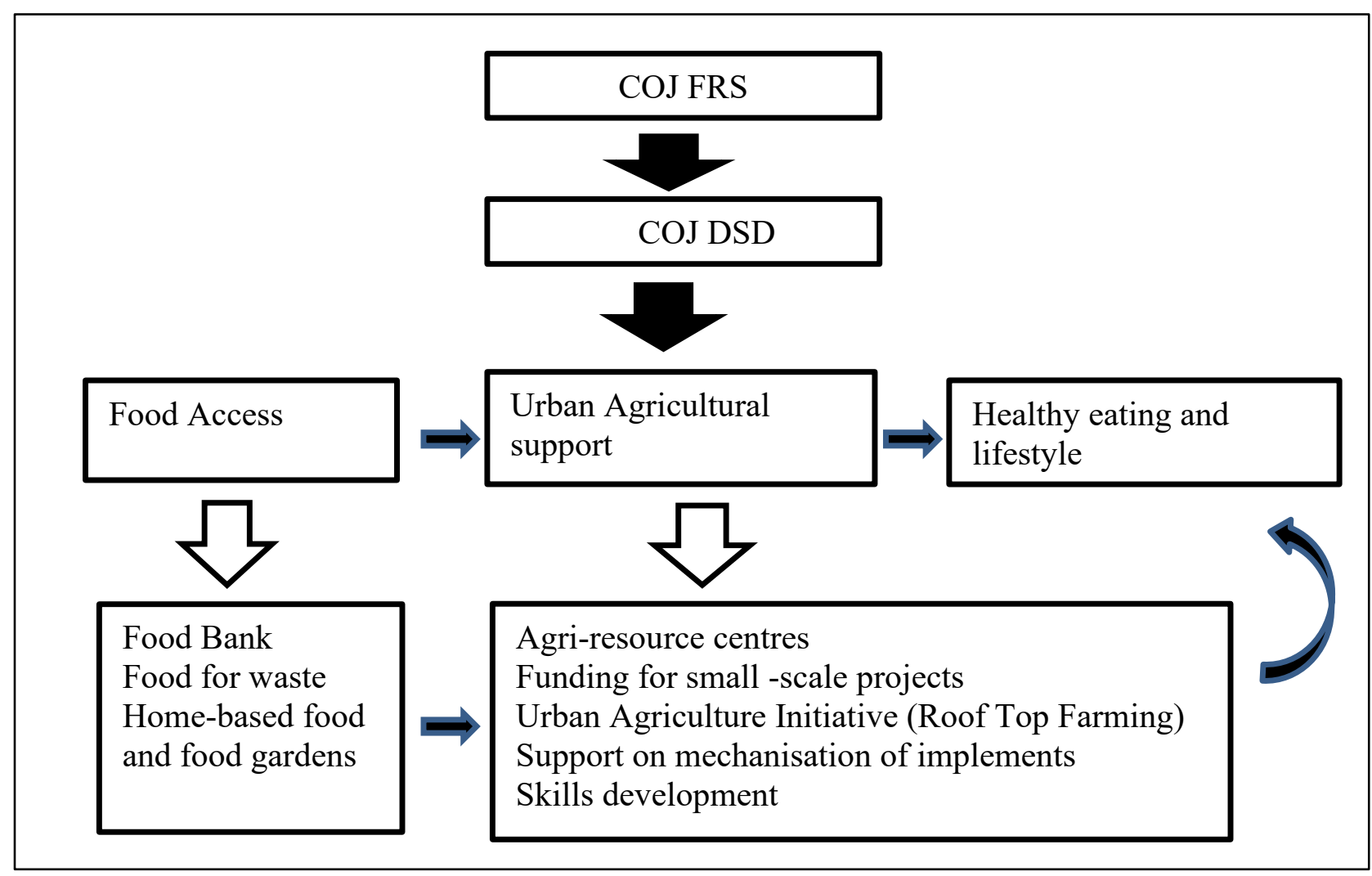

Fig. 1: Conceptual framework of the City of Johannesburg, Food Resilience strategy (FRS).

Source: Authors compilation

The social capital theory states that the ability of organisations to function optimally depends on the degree of confidence, standards, reciprocity, and the kind of relationships they may have with those in society (Malan, 2015, p. 85). These ties were further described as the bonding of social capital among similar participants in society and integrating and binding social capital across division lines (Malan, 2015, p. 65). The relationships necessitate the development of agriresource centres where agri-apprenticeship programmes support and contact communities, schools and micro-farmers at all levels.

The agri-resource centres are administered through the Urban Agricultural Programme (UAP) mandated to provide a sustainability model which encourages communities to cultivate their own food, promote economic growth and access markets (CoJ IDP, 2014, p. 85). Moreover, within the UAP initiatives and the social capital theory are the small-scale initiatives (Hub -and Spoke) which comprise of small enterprises, cooperatives and intensive small-scale crop and animal farming. Finally, the large-scale initiatives, such as food empowerment zones aim to support emerging farmers to sell their goods to food retail giants, alongside food processing and market access (CoJ IDP, 2014, p. 85).

Individual farmer participation in the social capital theory is presented by the WITS University Cooperative and Policy Alternative Centre (COPAC) convention on urban farming. It 
developed a 'food common' to market fresh fruit and vegetables from farms directly to Wits community consumers. Individual farmer organisations include Althea Holdings, Grasmere involved in organic farming, Belz, Greenz and Herbs, Braamfontein, hydroponics, Libapo, Soweto, agro-processor, chillies, and NYOC. NYOC is a registered beekeeping entity in the Department of Agriculture, Forestry and Fisheries (DAFF) (Perry, 2019).

The relationship amongst farmers through cooperatives are identifiable through initiatives such as Bertrams Inner City Farming, where organic vegetables, fruits and herbs are cultivated, as well as the Siyakhana Food Garden Project in the Bezuidenhout Valley Park including the Soweto Food Processing Initiative (Perry, 2019; van Staden, 2014).

A link between farmers and farmer organisations is visible in AgriSA, which promotes the growth, productivity, stability, and sustainability of primary agriculture in South Africa by formulating and implementing agricultural policy. Another example is the African Farmers Association of South Africa (AFASA), which aims to enhance African farmers' skills to engage in formal and informal markets effectively; and seeks to promote cohesion in the agricultural industry.

The social capital theory also underscores multi-stakeholder engagement strategies amongst farmers and various stakeholders to bridge social cohesion (Szreter, 2002, p. 579). Bridging and connecting issues may explain how food as a social phenomenon is related to broader social problems, such as safety and education and can serve as a reference in the organisation to multi-stakeholder activities. This is executed by multi-stakeholder participation in food conversations (Izindaba Zokudla) to generate prospects for urban agriculture in a sustainable food system (Malan, 2018). The social capital theory, which applies urban agriculture strategy, relies on how the conflicts between the civil society participants is mediated.

According to Sakai et al. (2020), a resilient, healthy, and sustainable food supply should be viewed as a matter of public good. It underpins public health, social equality, and environmental quality. The Leeds study conducted by Sakai et al. (2020) revealed that the city has plenty of farmland, expertise, innovation, excellent practice and minimal interventions could deliver significant changes and benefits. Furthermore, the authors recommend that Leeds City Council establish a high-profile task force to work with local stakeholders to create a local and sustainable food brand, improve access to land for growers, strengthen economic measures to support a vibrant local food ecosystem, promote and develop education and skills. Aliber (2009) analysed the official data to illustrate what is known about food expenditure and hunger, through the utilisation of Statistics South Africa's Income and Expenditure Survey (IES) and the General Household Survey (GHS). Furthermore, after analysing recent Statistics South Africa's Labour Force Survey (LFS) data, Aliber (2009) studied the potential contribution of smallholder production to food security.

Jacobs (2009) extended the analysis of food expenditure and hunger and accentuated under-nutrition. He explored diverse data sources associated with household access to a nutritionally adequate diet. Labadarios et al. (2009) undertook a technical approach to examine a broad range of national datasets utilised since 1994 to determine food and nutritional security. Their article introduced the nutritional dynamics of food security. Labadarios et al. (2009) also revealed the implications of utilising various indicators and sampling frames to determine food security levels in South Africa. Rudolph et al. (2012) studied the state of food insecurity in Johannesburg. The study revealed that poverty and food insecurity in Johannesburg is unacceptably high and appear to be closely related. Furthermore, a large proportion of the food insecure population was also highly vulnerable to shocks resulting from macro-economic trends 
(for example, fuel price hikes), environmental change and health issues such as Human Immune Virus (HIV) and Acquired Immunodeficiency Syndrome (AIDS), Tuberculosis (TB) and chronic illness. Also, each of the three study areas identified specific distinguishing characteristics, for example, certain related to the population's demographic profile, however, probably be a function of spatial and infrastructural factors. Rudolph et al. (2012) recommended that Strategies and policies to address food security and poverty should be informed by an appreciation of the complexity of the issues involved and address specific features evident for each area.

\section{City of Johannesburg: Food Resilience Strategy and Food Security}

The CoJ is faced with inter-generational cycles of poverty and hunger. According to the CoJ IDP (2019), $45 \%$ of the urban population (in the most deprived wards) is food insecure. This problem has posed serious challenges towards the development of the city. Moreover, escalation of the levels of food insecurity include macro-economic shocks such as fuel price hikes, which have a bourgeoning effect on food prices and unemployment; as well as Human Immune Virus (HIV) and Tuberculosis (TB). These shocks dissuade the working populations ability to contribute towards food security. Furthermore, the lack of appropriate skills and technology, also contributes towards the unemployment phenomenon (Rudolph and Kroll, 2012).

Parks Tau, former Africa National Congress (ANC) Mayor of CoJ, identified food insecurity as one of the critical challenges which affect the Johannesburg citizenry. Therefore, the need to formulate a policy to ensure that no one goes hungry was identified. During his State of the City address in 2013, the Mayor claimed that approximately $40 \%$ of the poor were susceptible to transitory food insecurity. Most households spend at least three days a month without a meal. Food poverty is affirmed by statistics from SACN (2018) and the South African Government News Agency (2013), which claimed that food (cost) accounts for approximately $30 \%$ of the affluent working-class income and about $60 \%$ of the middle-income to low-income households.

To fight food insecurity, the CoJ established the FRS in 2012 (CoJ IDP, 2013). The CoJ Department of Social Development (DSD) is the custodian of the policy and oversees its implementation. The Food Resilience Strategy outlines three levels of intervention towards food security: food access, urban agricultural support, and the promotion of both healthy eating and lifestyle.

Within the intervention, a variety of measures are utilised to combat individual hunger. Such steps include food coupons, food packages, backyard gardens and services that bind people into an income-generating activity, thereby enabling them to purchase food (provide access to food) (CoJ IDP, 2013).

To implement the intervention strategies, the CoJ partnered with many Non-Governmental Organisations (NGOs) to fulfil this mandate, specifically, the CoJ DSD which partnered with the Johannesburg Food Market to create a Food Bank initiative to provide immediate food and nutritional needs to the city's poor and vulnerable households (Joburg Market, 2018). The Food Bank is replenished by food donors, namely farmers, retailers, market agents and exporters who donate the food to help food insecure victims. The food undergoes a quality assurance check before it is distributed to the people.

Local resource collaboration supports the informal food procurement system to help farmers access essential resources, finance and advice on farming. Furthermore, farmers are assigned trading spaces or linear markets to sell their produce in the city (CoJ IDP, 2013). To bolster this initiative, the CoJ Food Resilience Unit in collaboration with United Way South Africa, implemented the UAP to support 600 smallholder beneficiaries. United Way South Africa 
mobilises communities to tackle poor education, burden of disease including enterprise development challenges. The programme supports farmers in the city with business and technical skills required to manage a farming venture, as well as access to markets. Moreover, support is provided through "hub-and-speak" infrastructure support, which connects local producers' network systems to cold chains, packing houses and wider distribution channels (Campbell and Malan, 2016; CoJ IDP, 2013).

In support of this initiative, the UAP creates partnerships between agricultural NGOs and farmers to design efficient farming technologies. Of prominence is the agreement of the city and Izindaba Zokoudla Co-Designs Farming Technology to provide support on the mechanisation of implements utilised to increase productivity. The produce is then sold to local markets, such as the Imvelo Market in Soweto, South Africa (Campbell and Malan, 2016a).

Apart from the mechanisation support component, the partnership between technological design NGOs and farmers offers farmer training support on relevant local farming knowledge. This is shared through internally arranged online portals. Furthermore, the partnerships can link universities, academics, entrepreneurs and multiple stakeholders in the creation of servicelearning, applied research ventures and companies that can lead to a food system which is socially sustainable, economically viable and environmentally friendly. In conformance herewith, the Izindaba Zokudla Farmers' School and Innovation Lab was established to enhance changes in the food system geared towards food security in the city. The school began as a farmer-to-farmer educational event, which eventually attracted experts. The courses focused on urban agricultural development, enterprise development and understanding the food system (Campbell and Malan, 2016b; CoJ IDP, 2013).

Within the FRS is the Access to Food goal, which aims to respond to the urgent needs of food recipients and ensure that all identified beneficiaries are assisted through initiatives such as the Food Bank, Food for Waste, Home-based Food and Food Gardens. Embedded in the strategy are key emancipation areas drawn from the Urban Agriculture Support unit to provide a viable business model to support communities to grow their food, facilitate access to markets and promote local economic development.

A variety of structures underpin the strategy's success. Firstly, the Agri-Resource Centres are community-based support networks for individuals/households and community-level agricultural development which were organized in all regions. Secondly, funding targeted areas of small-scale intensive crop projects and animal farming through cooperative and Small, Medium and Micro-Sized Enterprises (SMMEs).

In pursuing this mechanism, the CoJ created the Urban Agricultural Initiative (UAI) in partnership with the Johannesburg Inner-City Partnership to promote rooftop farming in the CoJ. According to Barkar (2018), the initiative is not just about growing food crops on top of roofs but strategically empower the urban population in changes to livelihoods. The initiative had rewarding success in the CoJ. By the end of 2017, the project trained 600 farmers on rooftop farming, produced 25 flourishing such farms, and created 120 full-time jobs and 280 part-time jobs for the CoJ residents (Barkar, 2018).

The FRS recognises the significance of farmers in the growth of urban agriculture through support for farmers at various levels of development. This includes large-scale support through the Food Empowerment Zone, which is available in large parts of land-based agriculture. It includes farms ranging from 1 hectare to more than 100 for sale to food retailers. Secondly, it supports 'emerging farmers' by dividing agricultural land into various parts for a group of SMMEs and cooperatives. The entrepreneur cluster comprises of approximately 50 farmers engaged in a variety 
of farming activities. These activities are divided into various enterprises, such as slaughterhouses, common cold chain and common distribution. Thirdly, the strategy provides private sector investment support, where a large share of the land on which emerging farmers operate is leased to a private sector partner on condition that they commit to a mentorship programme designed to establish emerging farmers in the food industry.

Furthermore, capacity building for food transformation' is provided where efforts are made to transform traditional food systems into processed food. In this regard, the city partners with various stakeholders, including the Small Enterprise Development Agency (SEDA) through the Gauteng Enterprise Propeller (GEP) incubator for food processing/agro-processing. Finally, market access is an option. The primary effort is to get markets closer to communities, either by creating retail outlets or through supply synergies with major retail outlets.

The success of these initiatives suggests that urban agriculture can be utilised to tackle food security in cities (Malan, 2015). Urban agriculture is a powerful trend in promoting sound food systems in urban areas. It improves the supply of fresh food in cities, reduces waste, and creates a decent standard of living for urban dwellers through employment and income-generating initiatives (Has, 2016).

\section{Policy Context}

According to section 27(1)(b) of the Constitution of South Africa (the Constitution), everyone has the right to access sufficient food and water. The Food Resilience Strategy falls under this regulatory framework. The Constitution clearly stipulates that everyone has the right to food, thus guiding this policy. Similarly, section 28(1)(c) of the Constitution prescribes that every child in South Africa has a right to basic nutrition, shelter, basic health care services and social services. Food security, therefore, implies the ability to access nutritious food on a continuous and sustainable basis. This obligation regulates the Food Resilience Policy, that is, every child has the right to basic nutrition, which, therefore, mandates the $\mathrm{CoJ}$ to implement food resilience measures through the Food Resilience Strategy to adhere to this regulation.

In the same way, the National Policy on Food Security and Nutrition (NPFS) (2013) has the strategic objective to ensure the availability, accessibility and affordability of healthy and nutritious food at all levels. NPFS (2013) objective is to comprehend the multi-sector complexity of food security by presenting approaches that include social initiatives, food production and delivery, as well as market, trade and procurement support to all stakeholders. The CoJ FRS implements the intentions of the NPFS policy through the Food Resilience Unit within which various poverty alleviation strategies are utilised.

Concurrently, the National Development Plan (NDP) (2013) has projected 2030 to reduce unemployment, poverty and inequality through food security. The NDP outlines steps which can be utilised towards food security in South Africa. These include "expanded use of irrigation, security of land tenure, especially for women and the promotion of nutrition education" (Department of Social Development (DSD), (2013:5). These steps provide a regulatory framework and direction of how the CoJ can implement the Food Resilience Strategy.

Furthermore, the Agriculture White Paper (1995) was introduced to promote food security by encouraging agriculture that targets previously disadvantaged groups and integrates them into a more competitive global environment. The paper, therefore, encourages the rethinking of current agricultural strategies to facilitate technological innovation, food security and nutrition. The policy and strategies embedded in the White Paper regulates the CoJ Food Resilience Strategy. It focuses strongly on sustainable urban agriculture through technological innovation to ensure food security. 
Finally, the Household Food and Nutrition Security Strategy (HFNSS) ensures the accessibility, availability and sustainability of healthy and nutritious food at national and household levels.

Additionally, it guarantees that food and nutrition security approaches are effective, comprehensive and diverse (Mazenda, Obi, and Masiya, 2019). All these policies have a common thread to ensure the CoJ FRS effectiveness, which is discussed in the next section. The section will describe the processes, objectives and interlinkages of various coordinating sections. Once these issues are defined, the challenges which affect the implementation of the Strategy is expounded upon. Finally, recommendations and conclusions for identified challenges in the implementation of the Strategy is provided.

\section{Research methodology}

This article adopted a qualitative case study approach based on a systematic review of documents related to food security, food resilience and food policies in the $\mathrm{CoJ}$ and South Africa. Document analysis enables researchers to understand aspects of social life and generate possible themes for analysis (Patton and Cochran, 2002). The approach follows the objectivism philosophy, which requires that social phenomena exist independently of social actors. It responds to questions vis-àvis reality (Bryman and Bell, 2011, p. 11). The article is based on unobtrusive research techniques, which allow for studying participants' social behaviour, eliminate researcher bias or manipulate study objects (Auriacombe, 2016, p. 6). Unobtrusive assessment relies on secondary data in the public domain (Auriacombe, 2016, p. 6), while unobtrusive techniques are analysed conceptually, historically, in context and comparatively (Auriacombe, 2016, p. 7-11).

The content analysis was utilised to extract major themes relating to the research problem. Content analysis provides rich, detailed information on elements which could not be collected by other data-gathering methods, such as surveys, because most are limited in scope (Webb and Auriacombe, 2006, p. 592). Research synthesis was utilised in the selection of studies for inclusion in the content analysis. Figure 2 below illustrates the steps followed to select studies for inclusion in the content analysis.

Atkinson et al. (2014) define research syntheses (Figure 2) as the process of locating and selecting relevant research for inclusion. Giner-Sorolla (2012) further argues that a research synthesis is a useful tool to determine whether and under which conditions a research finding has been repeated. As a result, research synthesists should include extensive descriptions of the procedures employed to define problems, acquire literature, assess the relevance of reports, extract information from reports, integrate data, and draw inferences. The meta-analysis, in particular, enables a systematic search for influences on outcomes and the evaluation of potential sources of bias. Price (1965) underscores that the results of research synthesis frequently supplants primary research as the arbitrator of current knowledge. Cooper (2010) believes that research synthesists should be subjected to the same reporting criteria as primary researchers. Atkinson et al. (2014) propose the following five methodologies associated with research syntheses utilised in this article: reference database searches, journal and bibliography searches, reference list reports and citation searches, including direct contact searches.

Reviewed primary documents included the CoJ Integrated Development Plans (2013, 2016, 2017, 2018, 2019); Urban Food Security (2012); Agricultural Economics Research, Policy and Practice in Southern Africa (2015); and the State of Food Security in Southern African cities SASCN (2018). The selection of these articles and other academic publications is motivated by their relevance to enhance food security in local municipalities. 
To draw meaning from the documents, a thematic analysis was utilised. The thematic analysis accentuates identifying, examining and recording data patterns significant in responding to the research questions (Patton and Cochran, 2002).

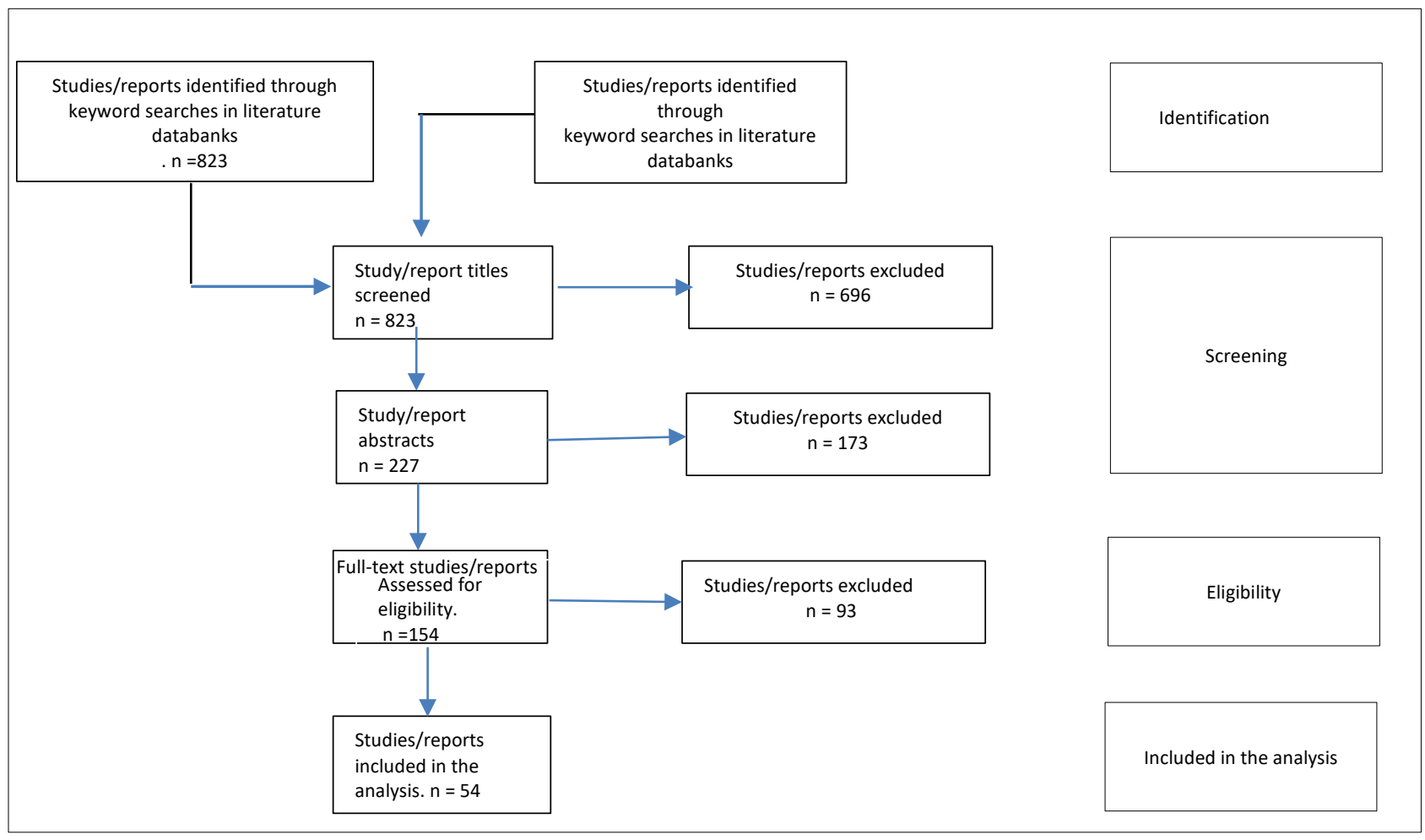

Fig. 2: Selection of studies for inclusion in the analysis

Source: Authors compilation

\section{Results and Analysis}

This section reflects on the challenges which affect the implementation of the FRS in the CoJ, through a thematic analysis. Table 1 below summarizes the selected themes and key documents which were utilized.

\section{Institutional challenges}

The food resilience unit is located in the DSD of the CoJ, which has affected the policy implementation thereof. The DSD of the COJ acts as the custodian of the policy and oversees its implementation. However, due to perceptions that the Department is responsible for intervening in the most impoverished communities, the location of food security under its ambit, instead of the Department of Economic Development, has made it problematic to elevate its programs to a strategic level (CoJ IDP, 2018). This has led to food security interventions being perceived as subsistence-led, which appeals to the most impoverished communities without any opportunity for creativity in this space. As a result, attracting the youth to participate in various programs has become problematic because they consider them of no economic benefit. The sustainability of the strategy is thus questionable because many of the adults involved are now considered to be 
"ageing". The weakened mandate on the Food Security Strategy also manifests itself through various CoJ departments and entities which have not been collaborating well to integrate food security in conformance with policy. There has been limited scope to integrate opportunities by various departments and entities, thereby resulting in many programs functioning in silos and scattered across the city (Nino, 2020).

\begin{tabular}{l|l}
\hline \multicolumn{1}{c|}{ Selected theme } & \multicolumn{1}{c}{ Selected documents } \\
\hline Institutional challenges & CoJ MTB (2019) Nino, et al, (2020). \\
\hline Economic factors & $\begin{array}{l}\text { Crush and Frayne, (2011) } \\
\text { Malan (2015); United Way South Africa } \\
\text { (2020); SACN, (2018) }\end{array}$ \\
\hline Urban agriculture contribution & $\begin{array}{l}\text { Dubbeling, et al. (2010); African Food } \\
\text { Security Network (2011), Frayne, et al., } \\
\text { 2014; Girard, (2012); Stewart, et al., (2013); } \\
\text { CoJ IDP (2020); Nino, et al, (2020). }\end{array}$ \\
\hline Access to land and water & $\begin{array}{l}\text { Malan (2015); CoJ Land Use Scheme } \\
\text { (2018); Crush and Tevera (2011) }\end{array}$ \\
\hline Macro-economic trends and health issues & Crush (2012); CoJ IDP (2020) \\
\hline Mitigating environmental issues & FAO (2019). \\
\hline Skills capacity and knowledge transference & $\begin{array}{l}\text { United Way, South Africa (2020). Malan } \\
\text { (2015). }\end{array}$ \\
\hline
\end{tabular}

Table 1: Selected themes and documents

Source: Authors compilation

As previously stated, while the government under the former executive Mayor Parks Tau pronounced food security as a priority, Herman Mashaba's Democratic Alliance (DA) successor prioritized the delivery of electricity, infrastructure and public safety. This is demonstrated by the CoJ MTB (2019:23) trends from 2016 to 2019/20 mid-term budget which reveals an average electricity allocation of 13 million Rand, 2 million Rand for public safety, 1 million Rand for housing and approximately 250000 Rand for social development. The poor expenditure allocation in the DSD, which administers the Food Resilience Strategy, has inhibited efforts to cushion people against food insecurity. Poverty alleviation projects have been abstract. Moreover, development in the Agri-Resource Centers is lagging. Since 2013, few centers have been established.

While opportunities exist to collaborate with the private sector and other stakeholders, the CoJ remains restricted by the bureaucracy that compels it to follow specific strict supply chain processes as per the Municipal Finance Management Act No. 56 of 2003 (MFMA). The MFMA's strict process in procuring service providers and securing partnerships has resulted in the 
Department losing opportunities presented by stakeholders. For example, the Department cannot approach a single partner without a competitive tender process, which often takes months to finalize. Also, some partners require collaboration which result in profits and sustainability. However, the MFMA (Act) does not allow the Department to profit. Even if proceeds are shared as surplus, the Act is silent on how the Department should record and spend the aforementioned.

There have been difficulties to integrate farmers in the value chain system, because of threats by established food chains. While the CoJ has attempted to integrate farmers into the value chain through the Joburg Fresh Produce Market, it has been a daunting task to organize the farmers. Organized farmers are required to benefit from economies of scale through sharing space, bulk supply and packing, including other marketing-related benefits.

\section{Economic factors}

The Food Resilience Strategy of the CoJ focuses intensely on agriculture as a plan towards food security. It ignores economic factors which play a significant role in triggering food insecurity amongst citizens (Crush and Frayne, 2011). According to Malan (2015), in studying the strategy, one can arguably state that farmers are the most important players. However, it ignores other critical factors such as employment patterns, food markets and pricing and the spatial configuration of the city. With this in effect, the municipality underscores that increasing production as a response to hunger is inadequate to address food security if other economic factors are not addressed. This is further affirmed by the United Way' South Africa (2020) report on the support provided to 600 urban farmers in the Gauteng region, administered through the UAP, in partnership with the Department of Social Development and the Food Resilience Unit.

Similarly, Crush (2012) contends that food security in the CoJ is principally related to income, which is the ability of a household to buy food (accessibility). In summary, household income, unemployment and food insecurity are strongly related. Households with a full-time member of the labor force are much more likely to be food secure. Households with a participant in part-time or casual jobs are, therefore, marginally less likely to be food-secure. Ultimately, unemployed households are expected to become more food insecure (Crush, 2012; SACN, 2018).

Therefore, the challenge in the CoJ is not related to the availability of food, which the Food Resilience Strategy accentuates but rather accessibility to food emanating from unemployment and lack of income. Most households in the city are susceptible to hunger and starvation; as such, employing the Food Resilience Strategy should strongly underscore reduction in unemployment and create income-generating projects.

\section{Urban agriculture contribution}

One significant way to promote food security in cities is through urban agriculture. Dubbeling et al. (2010) argue that urban agriculture is widely considered a mechanism to tackle food insecurity and promote social inclusion. Malan (2015), however, cautions the potential challenges of urban agriculture, because its classification is still subject to controversy, that is, it differs from rural agriculture, with questionable addition of nutritional value (Frayne et al., 2014; Girard, 2012; Stewart et al., 2013).

Consequently, Crush and Frayne (2011); and Nino Lane, Okano, Rahman, Peng, and Benn (2020) argue that urban agriculture plays a minor role in the availability and supply of food in the CoJ. Urban agriculture is practied primarily by those who have access to land or are food insecure. These assertions are corroborated by the African Food Security Network (2011), which revealed that most people who practice urban agriculture in $\mathrm{CoJ}$ are motivated by a need to survive and not 
commercial gain. Commercializing urban agriculture has no significant effect on food security, because $77 \%$ of the farmers involved in urban farming were food insecure. CoJ IDP (2020:17) participation in citizenry urban farming is merely for subsistence and not commercial purposes (Crush and Frayne, 2011). Drawing from these arguments, urban agriculture needs support in education, capacity and mechanization to enhance food security.

\section{Access to land and water}

Ensuring food security in urban areas can be done by improving access to land and water because the Food Resilience Strategy's UAP is constrained by the scarcity of both. Malan (2015) argues that the Food Resilience Strategy has implemented programs for farmers to access land through the Department of Land and Agrarian reform. However, not all urban farmers benefitted. Therefore, the Food Resilience Policy was ineffective because land is not readily available. Furthermore, the urban agricultural land market is mainly informal, and most farmers do not own or have legal access to said land (Crush and Tevera, 2011). Moreover, the CoJ Land Use Scheme (2018, pp. 14 \& 59) confirmed that smallholder urban farming is constrained by a lack of land access. The most popular methods of accessing cultivated land include leasing and usage rights, which most farmers cannot afford.

Additionally, the available urban land is marginal. It is generally located around parks, riverbeds and roadsides. In combination with the poverty-stricken and land-tenure situation, farmers are reluctant to invest in the land. From the crops cultivated, the nutrition content is questionable due to planting during a generally non-nutritious short season (early maturing varieties). Moreover, the struggle for land tends to impede the strategy's food security processes.

\section{Macro-economic trends and health issues}

The Food Resilience Strategy does not adequately address the macro-economic trends which impede the economic abilities of the urban poor households and civilians negatively. Both Crush (2012) and the CoJ IDP (2020:18) observe that most urban poor are significantly vulnerable to sudden macro-economic factors and trends, for example, fuel hikes, environmental changes (drought) and health issues (growth of HIV and Tuberculosis TB). Presently, health shocks as a result of the Covid-19 pandemics have worsened the plight of citizens because many industries shut down, and the already high unemployment rate exacerbated further. Since the declaration of the state of disaster in March 2020, the unemployment in the city has increased by $40 \%$, which has resulted in many resorting to seek assistance from the Unemployment Insurance Fund (UIF) for basic income to access food. Micro-economic trends and challenges such as fuel price hikes have had a multiplier effect on food prices, resulting in deteriorating purchase power and consequently, unemployment as a result of high production costs. The consequences of these macro-economic shocks affected the household access to food. The policy needs to assess measures which can help the city respond to macroeconomic shocks, which have hurt food security in Johannesburg.

\section{Mitigating environmental issues}

The Food Resilience Strategy has not dictated any information and direction to respond to environmental changes and challenges that may affect urban agriculture or food security. Environmental challenges such as drought and global warming affect food security substantially, particularly its availability and accessibility within a region (FAO, 2019:74). The Strategy must ensure that measures are implemented to confront environmental factors that may affect the food system, farming, and, most importantly, households' food security. The Strategy hardly accentuates food systems which can help the city to be food secure during a drought or any 
environmental condition. There is a need for the policy to integrate food net systems for any environmental factors which may cause harm the execution of policy to protect the citizens from food insecurity, especially the urban farming policy, which is highly affected by environmental factors. However, in an attempt to address this concern, the city, in partnership with the United Nations Environment Programme (UNERP), has begun promoting organic farming to mitigate unsustainable agricultural practices which has a negative impact on climate change.

\section{Skills capacity and knowledge transference}

Farmers lack necessary skills to implement the FRS in its entirety (United Way, South Africa, 2020). Similar concerns are shared by Malan (2015), who reveals that urban farmers lack the direction in which farming should be approached to develop skills. The recommended expert farmer approach has not been adequately supported, nor is it expressly stated in the FRS. Moreover, farmers are not well-acquainted with the latest innovative technologies to farm effectively. This should be addressed and supported by government and other NGOs, because technological innovation is the key to effective agriculture production and the successful implementation of the FRS (United Way, South Africa, 2020). Furthermore, innovative farming techniques should be promoted among the youth who have the appetite for the $4^{\text {th }}$ Industrial Revolution. Such innovative technologies in farming will enhance sustainability, change perceptions among the youth, and attract them to participate in urban agriculture to improve food security and economic development.

\section{Recommendations}

Socioeconomic factors have accentuated the level of poverty in the CoJ. There is a need to reconsider the FRS policy framework and align the Strategy objectives with socioeconomic factors. Consequently, improving access to water, electrification and sanitation services, and train urban farmers, and focus primarily on changing the perceptions among the youth, is critical for the city's food security. Access to international markets through exports is necessary to increase urban farming returns. Moreover, synergies should be created among small scale farmers and household farming units in adding value and maximize the support rendered by the CoJ. The CoJ needs to consider relocating food security to the Department of Economic Development. In this way, the programs will be perceived differently, that is, as having potential for economic benefits, attract the youth base and those who intend to enterprise in this field.

There is a need for the CoJ to elevate food security to a mayoral priority to attract budgetary attention for capital expenditure purposes. Furthermore, the $\mathrm{CoJ}$ needs to locate the contribution of food security in other pronounced mayoral priorities such as 'ensuring job-intensive economic growth'. This would ease the incentive for the required resources.

To boost partnerships in food security, the CoJ may need to prioritize working with other organs of State such as universities and public research entities. Securing services from another organ of State can be done through section 110 (2a) of the MFMA, which does not require the city to utilize a tender process. All the city would need to prove is that the services are indeed from the organ of State and that there are financial savings compared to securing services from the market.

\section{Conclusions}

Food insecurity amongst the residents of African urban cities has called for the implementation of numerous programs by their respective metropolitan municipalities to reduce hunger. The FRS is one such initiative implemented by $\mathrm{CoJ}$ to address food and nutrition challenges. To fully gauge the scope of the issue, this article adopted a qualitative case study design and utilized document 
analysis to analyze the challenges which affects the implementation of the CoJ FRS to address the citizenry's poverty and food security problems. The study revealed skills capacity and knowledge transference, access to land and water, institutional challenges, economic factors, urban agriculture production and environmental factors as central themes and challenges to implementing the CoJ FRS. It is, therefore, necessary to integrate diverse stakeholders in the design and implementation of the Food Resilience Strategy. Moreover, synergies should be fostered between the local producers and the local markets.

\section{COI: The authors confirm that there is no conflict of interest}

\section{References}

Ahs, J. (2017). The policy process behind the adaptation of Urban Agriculture policy in Cape Town and Johannesburg: Academic activists and NGO's as policy actors. Linnaeus University: 24-32 Available at: http://www.divaportal.se/smash/get/diva2:1067977/FULLTEXT01.pdf (Accessed 15 May 2020).

Aliber, M. (2009). Exploring Statistics South Africa's national household surveys as sources of information about food security and subsistence agriculture. Unpublished report, Centre for Poverty Employment and Growth, Human Sciences Research Council, Pretoria.

Altman M, T Hart, GB; Jacobs, P.T. 2009. Household food security status in South Africa, Agrekon, 48:4, 345-361, DOI: 10.1080/03031853.2009.9523831

Atkinson, K.M., Koenka, A.C., Sanchez, C.E., Moshontz, H., \& Cooper, H. (2015). Reporting standards for literature searches and report inclusion criteria: making research syntheses more transparent and easier to replicate. Research Synthesis Methods, 6(1), 87-95. https://doi.org/10.1002/jrsm.1127

Auriacombe, C. (2016). Towards the construction of unobtrusive research techniques: critical considerations when conducting a literature analysis. African Journal of Public Affairs, 9(4), 1-19.

Barker, A. (2018). Urban Agriculture Initiative. The Johannesburg Inner City Partnership. Available at: http://www.jicp.org.za/urban agriculture initiative/ (Accessed 12 August 2020).

Bryman, A., \& Bell, E. (2011). Business research methods ( ${ }^{\text {rd }}$ ed.). Cambridge; New York, NY: Oxford University Press.

Campbell, A.D., \& Malan, N. (2016 a). Izindaba Zokudla. Design for Social Innovation and Sustainability. Available at: https://www.desisnetwork.org/wpcontent/uploads/2016/03/2014_PrjFormat_AngusNaude.pdf (Accessed 10 September 2020).

Campell, A.D., \& Malan N. (2016 b). Izindaba Zokudla (Conversation about Food). Innovation in the Soweto Food System. In Abendroth, L.M. \& Bell, B. Public Interest Design Education Guidebook: Curricula, Strategies and SEED Academic Case Studies, 2018.Taylor and Francis, New York.

City of Johannesburg. (2020). Integrated Development Plan: 2018/19 Review. Available at: https://www.joburg.org.za/Documents/2019\%20Notices/COUNCIL\%20NOTED\%20201 9-20\%20DRAFT\%20IDP\%20REVIEW.pdf (Accessed 13 February 2020). 
City of Johannesburg. (2018). Integrated Development Plan: 2018/19 Review. Available at: https://www.joburg.org.za/documents_Documents/Intergrated $\% 20$ Development $\% 20$ Plan /idp\%20documents/IDP\%20for\%20Council\%20(2).pdf (Accessed 13 May 2020).

City of Johannesburg. (2013). Integrated Development Plan. 2013/14 Review:81. Available at: https://www.joburg.org.za/documents_Documents/Intergrated\%20Development\%20Plan 2013-16\%20IDP\%2017may2013\%20final.pdf (Accessed 23 August 2018).

City of Johannesburg. (2018). Land Use Scheme. Available at: https://www.joburg.org.za/documents/Documents/City\%20of\%20Johannesburg\%20Lan d\%20Use\%20Scheme\%20-\%20FINAL\%202018.pdf (Accessed 13 February 2020).

City of Johannesburg Medium Term Budget. (2019/20). Available at: https://www.joburg.org.za/documents /Documents/Budget/DRAFT\%20Budget\%202019 20/2019-20\%20BUDGET\%20BOOK.pdf (Accessed 25 September 2020).

Cooper, H. (2010). Research synthesis and meta-analysis: A step-by-step approach (5 $5^{\text {th }}$ ed.). SAGE Publications, Inc.: Thousand Oaks, CA.

Crush, J. (2012). The State of Food Insecurity in Johannesburg. Urban Food Security, 1(12):923.

Crush, J., \& Frayne, B. (2011). Urban food insecurity and the new international food security agenda. Development Southern Africa, 4(28), 527-528.

Crush, J., \& Tevera, D. 2011. Food security in Southern African cities: the place of urban agriculture. Progress in Development Studies, 4(11), 196-288.

Department of Social Development. (2018). National Policy on Food and Nutrition Security. Republic of South Africa. Available at: https://www.nda.agric.za/docs/media/NATIONAL\%20POLICYon $\% 20$ food $\% 20$ and $\% 20$ nutrirition\%20security.pdf (Accessed 23 September 2020).

Devereux, S. (2001). Sen's Entitlement Approach: Critiques and Counter-critiques. Oxford Development Studies, 29(3):245-263.

Dubbeling, M., De Zeeuw, H., \& Van Veenhuizen, R. (2010). Cities poverty and food: MultiStakeholder policy and planning in urban agriculture. Rugby: Practical Action Publishing.

Du Toit, D. (2011). Food Security. Department of Agriculture, Forestry and Fisheries: Republic of South Africa: 2. Available at: https://www.nda.agric.za/docs/genreports/foodsecurity.pdf (Accessed 11 July 2020).

Food and Agriculture Organisation. (2019). The State of Food Security and Nutrition in the World. Available at: http://www.fao.org/3/ca5162en/ca5162en.pdf

FAO. (2018). Corporate Document Repository. Definition of policy. Available at: http://www.fao.org/wairdocs/ilri/x5547e/x5547e05.htm (Accessed 11 September 2020).

Food and Agricultural Organization of the United Nation. (2018). The Right to Food. Available at: http://www.fao.org/right-to-food/en/ (Accessed 5 March 2020).

Food and Agricultural Organization. (2009). World Summit on Food Security. Draft Declaration of the World Summit on Food Security. Available at: http://www.fao.org/fileadmin/templates/wsfs/Summit/Docs/Declaration/WSFS09_Draft Declaration.pdf (Accessed 16 May 2021).

Frayne. B., McCordie, C., \& Shilomboleni, H. 2014. Growing out of poverty: Does urban agriculture contribute to household food security in Southern African cities? Urban Forum. Available at: http://link.springer.com/article/10.1007\%2Fs12132-014-9219-3 (Accessed 15 May 2020). 
Giner-Sorolla, R. (2012). Science or art? How aesthetic standards grease the way through the publication bottleneck but undermine science. Psychological Science, 7, 562.

Girard, A.W., Self, J.L., McAuliffe, C., \& Olude, O. (2012). The effects of household food production strategies on the health and nutrition outcomes of women and young children: A systematic review. Paediatric and Perinatal Epidemiology, 26(1), 205-222.

Hendricks, S. (2013). Food Security in South Africa: Status Quo and Policy Imperatives. AEASA Presidential Address, 52(2), 1-4.

Joburg Newsroom. (2015). Food parcels keep hunger at bay. Available at: joburg.org.za/media_Newsroom/Pages/2016\%20\&\%202015\%20Articles/food-parcelskeep-hunger-at-bay-ID9959.aspx (Accessed 11 May 2020).

Kroll, F., Rudolph, M., Ruysenaar, S., \& Dlamini, T. (2012). The State of Food Insecurity in Johannesburg. AFSUN Food Security Series, (12).

Labadarios, D., Swart, R., Maunder, E.M.W., Kruger, H.S., Gericke, G.J., Kuzwayo, P.M.N., Ntsie, P.R., Steyn, N.P., Schloss, I., Dhansay, M.A., Jooste, P.L., \& Dannhauser, A. (2008). Executive summary of the National Food Consumption Survey Fortification Baseline (NFCS-FB-I) South Africa, 2005. South African Journal of Clinical Nutrition, 21(3) (Suppl. 2), 247-300.

Malan, N. (2015). Urban farmers and urban agriculture in Johannesburg: Responding to the food resilience strategy. Agrekon, 54(2), 51-75.

Malan, N. (2018). iZindaba Zokudla: A history. Anthropology and development Studies, University of Johannesburg .10.13140/RG.2.2.13706.52165.

Mazenda, A., Obi, A., \& Masiya T. (2019). An analysis of BRICS Food Policies, Strategies, and Trade in achieving Zero hunger: Lessons for South Africa. Africa Insight, 48(4), 148-160.

Nino, E.C., Lane, S., Okano, K., Rahman, I., Peng, B., \& Benn, H. (2020). Urban agriculture in the Gauteng City-Region's green infrastructure network. GCRO OCCASIONAL PAPER\# NO. 15. Available at: https://cdn.gcro.ac.za/media/documents/Urban_Agricilture_OP_final_July_2020.pdf (Accessed 22 September 2020).

Patton, M., \& Cochran, M. (2002). A Guide to Using Qualitative Research Methodology. Available at: https://cloudfront.ualberta.ca/-/media/science/research-andteaching/teaching/qualitative-research-methodology.pdf (Accessed 25 September 2020).

Perry, S. (2019). The Food Sovereignty Campaign. One Campus - Two Plates: urban farmers bridging the food choice divide of students on Wits Campus Newsletter. No 23. September 2019. Available at: https://copac.org.za/wp-content/uploads/2020/01/Newsletter-23.pdf (Accessed 25 September 2020).

Price, D. (1965). Networks of scientific papers. Science 149: 510-515.

Sakai, P., Bliss, T., Woodcock, S., \& Goldring, A. (2020). Growing a resilient food system in Leeds Brief 1, SRI 28, 21 Sept 2020. University of Leeds. Available at: https://doinggoodleeds.org.uk/event/building-food-resilience-webinar/. (Accessed 25 September 2020).

Sen, A. (1981). Poverty and Famines: An Essay on Entitlement and Deprivation. Oxford: Clarendon Press.

Sopamena, J., Sukesi, K., \& Hidayat, K. (2017). Local Wisdom and Food Resilience in Selaru Island Community of Maluku Province. International Journals of Sciences and High Technologies, 5. 168-174. 
South African Cities Network (SACN). (2018). Urban Conference Report.2018. Available at: http://www.sacities.net/wpcontent/uploads/2019/06/Urban\%20Conference\%202018\%20 Report_FINAL [FV].pdf (Accessed 25 September 2020).

Stewart, R., Körth, M., Langer, L., Rafferty, S., Rebelo Da Silva, N., \& Van Rooyen, C. (2013). What are the impacts of urban agriculture on food security in low and middle-income countries? Environmental Evidence, 2(7), 14-22.

South Africa, Republic. (1996). Constitution of the Republic of South Africa. Pretoria: Government Printer.

Szreter, S. (2002). The state of social capital: Bringing back power, politics and history. Theory and Society 31(5): 573-621.

Rudolph, M., Kroll, F., Ruysenaar, S., \& Dlamini, T. (2012). The State of Food Insecurity in Johannesburg. Urban Food Security Series No. 12. Bronwen Muller, Cape Town.

South African Government News Agency. (2013). Joburg prioritises food resilience, agri development. Available at: https://www.sanews.gov.za/south-africa/joburg-prioritisesfood-resilience-agri-development (Accessed 22 September 2018).

The Joburg Market Food Bank: Available at: http://www.joburgmarket.co.za/foodbank.php (Accessed 3 August 2018).

United Way, South Africa. (2020). Connecting Low Income South African Farmers to Sustainable Economic Opportunities. Available at: http://www.unitedway.org.za/connecting-lowincome-south-african-urban-farmers-sustainable-economic-opportunities (Accessed 13 March 2020).

United Nations Human Rights Council. (2008). Human Rights Council Resolution 7/14. The right to food. Accessed 12 December 2019. Available at: https://ap.ohchr.org/documents/E/HRC/resolutions/A HRC RES 7 14.pdf

Van Staden, F. (2014). City Farms Earthworks, October- November 2014. Available at: https://www.jtross.co.za/news/city-farming/

Webb, W., \& Auriacombe, C.J. (2006). Research design in public administration: critical considerations. Journal of Public Administration, 41(3), 588-602. 